University of Michigan Law School

University of Michigan Law School Scholarship Repository

1917

\title{
Limitations Upon the Use, After Sale, of Patented Articles
}

\author{
John B. Waite \\ University of Michigan Law School
}

Available at: https://repository.law.umich.edu/articles/1346

Follow this and additional works at: https://repository.law.umich.edu/articles

Part of the Intellectual Property Law Commons, and the Supreme Court of the United States

Commons

\section{Recommended Citation}

Waite, John B. "Limitations Upon the Use, After Sale, of Patented Articles." Mich. L. Rev. 15, no. 7 (1917): 581-4.

This Response or Comment is brought to you for free and open access by the Faculty Scholarship at University of Michigan Law School Scholarship Repository. It has been accepted for inclusion in Articles by an authorized administrator of University of Michigan Law School Scholarship Repository. For more information, please contact mlaw.repository@umich.edu. 
Limitations Upon The UsE, after Sale, of Patented ARTicles.-In the case of Motion Picture Patents Co. v. Universal Film Co., 37 Sup. Ct. $4 \mathrm{I} 6$, the Supreme Court has just rendered a decision which reverses the much discussed case of Henry v. Dick Co., 224 U. S. I. The opinion was by a divided court, however, as three of the justices dissented, and Justice McREYNOLDS "concurred in the result" only. It can, therefore, hardly be said to settle the ultimate rule as in contradiction to that followed in Henry $\nabla$. Dick Co., and discussion of the case is of something more than mere academic value.

The facts were that the plaintiff was owner of a patent covering a necessary part of the mechanism on moving picture projecting machines. This particular device was of such efficiency as to be in general use, to the practical exclusion of all substitutes. The plaintiff granted a license to manufacture and sell these parts, the licensee agreeing that it would not sell them except under agreement with each vendee, for himself and his assigns, that they should be used only with a certain type of film. This licensee sold a machine 
to an exhibition company which, in turn, transferred it to the defendant, the Prague Amusement Company. There was no privity of contract between this defendant and the plaintiff, but the defendant took the machine with notice of the restriction. The defendant, the Universal Film Manufacturing Company, supplied films to the Prague Company for use on the machine, having itself been notified of the restriction. The question raised was whether the restriction upon the use of the machine was enforcible against one not a party to the agreement, but who had notice of it.

The restriction is, in appearance, one upon the full and free enjoyment of a corporeal chattel, placed there by an erstwhile owner who has parted with the title. The obvious inquiry is whether limitations upon the perfect ownership of personal property are enforcible in the courts.

It may be said at the outset that in this particular respect the Patent Statute does not affect the inquiry. It provides nothing in respect to the ownership of property nor its transfer, except in the indirect way to be referred to later. All it does is to create a new form of incorporeal property, namely, the legal right in a patentee to exclude others from enjoyment of his invention. The invention itself is not corporeal, it is a concept of means to an end. It is the "ownership" of this concept which the Patent Statute creates.

Whether restrictions upon the enjoyment of personal property are enforcible at common law is undecided. Negative restrictions upon the complete enjoyment of real property may be so created as to be enforcible at law, or, as in England, in equity, against subsequent owners acquiring the property with notice. TIFFANY, REAL Prop., §349. The reason given by one court, (Parker v. Nightingale, 6 Allen 34I, 83 Am. Dec. 632), is simply that "restrictions and limitations which may be put on property by means of such stipilations, derive their validity from the right which every owner of the fee has to dispose of his estate, either absolutely or by a qualified grant, or to regulate the manner in which it shall be used and occupied." Restrictions as to the type of use of real estate are common. Blakemore v. Stanley, 159 Mass. 6; Keening v. Ayling, I26 Mass. 494.

The fundamental reason for allowing them is of course merely one of public policy, and its expression, as formulated by the court quoted from, applies to personal property as pertinently as it does to real estate. But that it does not in fact extend to personal property is indicated in occasional dicta. A writer in 28 LAW QuARTERLY REVIEw, 73, says, "In the case of chattels generally, any restriction as to their use can only be imposed by means of a contractual relation between a vendor and his purchaser, and will extend no further than the contractual relation extends." He cites no authority, however, and the present writer can find none except in respect to restrictions upon the re-sale price. Although these particular restrictions are held unenforcible, that does not necessarily indicate a difference between other-restrictions on personalty and those on realty, because restrictions upon the alienation of real property are also held in disfavor by the courts. GRAY, RESTRAINTS on AIIENATION. In some of the cases holding price restrictions unenforcible there are intimations that all restrictions come under the 
same rule. Thus the court in John D. Park \& Sons v. Hartman, I53 Fed. 24,39 , in passing upon the validity of a system of contracts restricting re-sale price, says, "It is also a general rule of the common law that a contract restricting the use or controlling sub-sales can not be annexed to a chattel so as to follow the article and obligate the sub-purchaser by operation of notice. A covenant which may be valid and run with land will not run with or attach itself to a mere chattel." See also, Taddy v. Sterious, [1904], I Ch. Div., 354; Dr. Miles Medical Co. v. Park \& Sons Co., 220 U. S. 373. A few other cases indicate, by analogy, a difference in respect to restrictions upon realty and personalty in holding that although express warranties run with the ownership of the former they do not follow that of the latter. Smith v. Williams, in $\mathrm{Ga} .782$; Prater v. Campbell, I 10 Ky. 23.

This uncertain state of the common law certainly permits a decision that restrictions upon its use can not be made to follow the ownership of a chattel. The decision in the Motion Picture Patents case is therefore perfectly sound, if one considers the restriction in that case as one sought to be imposed by the plaintiff upon the use of the projecting machine.

But was this restriction, after all, created by the plaintiff or any other owner of the chattel? Did the plaintiff not, rather, release, to a limited extent, a restriction upon the defendant's use of the chattel, which was actually imposed by the Patent Statute? Ownership of a chattel, however untrammelled by agreement it may be, does not ipso facto connote and carry with it an unrestricted right to use the chattel. By virtue of the Patent Statute, the owner is precluded from using it at all, if its use happens to constitute enjoyment of a patented invention. Even though the owner may have created the chattel himself, he is absolutely restrained from its use under such circumstances. The patentee of an invention may refuse permission to any or all owners of chattels, which embody his invention, to use them, however their ownership may have been come by. Continental Paper Bag Co. v. Eastern Paper Bag Co., 210 U. S. 405.

The writer can think of no reason why, if a patentee in his own discretion can forbid or permit an owner to use his property, he may not grant a modified permission, and limit the extent of the authorized use. It is at least the logical postulate that if the right to use, regardless of ownership, depends upon permission, wholly at the patentee's discretion, he may grant the right of use to such greater or less exent as his discretion dictates. When a patentee himself sells a tangible thing embodying his invention, the presumption is that he gives with it all the usual rights of ownership unrestricted by his own patent monopoly. But when in selling the thing he delimits the right of user by express stipulation, there is no room for any such presumption.

This has been the holding of practically all the cases prior to the principal one, although it must be confessed that reasons given have not always been either definite or consistent. The courts have upheld limitations which allowed invasion of the monopoly in a specified respect only (Pope Mfg. Co. $\mathbf{}$. Gormully, I44 U. S. 248), or for specified purposes only (Gamewell Firealarm Telegraph Co. v. Brooklyn, I4 Fed. 255), or which gave the right to use a particular machine on condition that no other machines of the same 
kind be used (United States v. Winslow, 227 U. S. 202), or to use the device only at the licensee's place of business (Rubber Co. v. Goodyear, 9 Wall. 788), or to use on condition that the product of the device should not be sold below a certain price (Bement v. National Harrow Co., 186 U. S. 70), or to use for a limited time only (Mitchell v. Hazoley, I6 Wall. 544). Permission to use only with certain films, seems to be an absolute analogy. It has been held, also, that one who voluntarily or otherwise pays full damages for having unauthorizedly made, used or sold a chattel embodying a patented invention does not thereby acquire any right to continued use or enjoyment of the chattel, nor is his vendee thereof in any better position. Birdsell $\mathrm{v}$. Shaliol, II2 U. S. 485. And this is despite the fact that the one so precluded from enjoyment is in all other respects the "owner" of the particular thing.

These restrictions have been enforced as though they were unreleased restrictions of the patent law, and not as limtations originally imposed by one individual upon another. This is the ground on which the decision was expressly based, in the English case of Incandescent Gas Light Co. v. Cantelo, I2 Rep. Pat. Cas. 262. "The patentee," said that court, "has the sole right of using and selling the articles, and he may prevent anybody from dealing with them at all. Inasmuch as he has the right to prevent people from using them or dealing in them at all, he has the right to do the lesser thing, that is to say, to impose his own conditions." In accord are, British Mutoscope \& Biograph Co. v. Homer, [rgor], I Ch. Div. 67I; National Phonograph Co. v. Menck, [19rx], A. C. 336. All of this authority is completely in accord with the holding of Henry v. Dick Co., which cites still other precedents.

When one recognizes the restriction of use in the Motion Picture Patents case for what it really is, namely, a limited release of a statutory restriction, and is not misled by its mere form of expression, the decision in the case is -learly in conflict with both logic and precedent. The court admits itself to ave been influenced by a feeling that the restriction, if sustained, "would be ravely injurious to that public interest, which we have seen is more a avorite of the law than is the promotion of private fortunes." The fault owever, if any, is with the Patent Statute which imposed the restriction, rather than with the patentee who relieved the public, at least to some extent, from its rigorous and absolute prohibitions.

J. B. W. 